\title{
A bibliography of the published writings of Dr Simon Walker
}

Compiled by Edmund King

\section{3}

'Lancaster v. Dallingridge: a franchisal dispute in fourteenth-century Sussex', Sussex Archaeological Collections, 111, 87-94.

\section{5}

'Profit and loss in the Hundred Years War: the subcontracts of Sir John Strowther, 1374', Bulletin of the Institute of Historical Research, 58, 100-6.

\section{6}

"John of Gaunt and his "affinity": a prosopographical approach to bastard feudalism', in Françoise Autrand (ed.), Prosopographie et histoire de l'état, (Paris), pp. 209-22.

\section{8}

'Geoffrey Chaucer and his family' and 'The Lollards', in Edmund King, Medieval England (Oxford), pp. 222-3, 242-3.

Review: Joan Greatrex, Account Rolls of the Obedientiaries of Peterborough (Northamptonshire Rec. Soc. 33, 1984), in English Historical Review, 103, 186-7.

\section{9}

'Law and lordship in the palatinate of Lancaster, 1370-1400', Journal of British Studies, 28, 325-48.

'Autorité des magnats et pouvoir de la "gentry" en Angleterre à la fin du moyen âge', in Philippe Contamine (ed.), L'état et les aristocraties, XIIIeXVIIe siècles (Paris), pp. 189-211.

'British History, 1200-1500', International Review of Periodical Literature, I, pp. 23-37.

Review: Nigel Saul, Scenes from Provincial Life: Knightly Families in Sussex, 1280 1400 (Oxford, 1986), in English Historical Review, 104, 721-2. 


\section{0}

The Lancastrian Affinity, 1361-1399 (Oxford Historical Monographs: Oxford; reprinted 1996), xii $+350 \mathrm{pp}$.

'Sir Richard Abberbury and his Kinsmen: the rise and fall of a gentry family', Nottingham Medieval Studies, 34, 113-40.

Review: Ralph A. Griffiths and James Sherborne (eds), Kings and Nobles in the Later Middle Ages (Gloucester, 1986), in English Historical Review, 105, 168-9.

\section{1}

'Letters to the dukes of Lancaster in 1381 and 1399', English Historical Review, $106,68-79$.

\section{2}

'A context for Brunanburh?', in Timothy Reuter (ed.), Warriors and Churchmen in the High Middle Ages: Essays Presented to Karl Leyser (London), pp. 21-39.

Review: S. J. Payling, Political Society in Lancastrian England: The Greater Gentry of Nottinghamshire (Oxford, 1991), History, 77, 292.

Review: W. M. Ormrod, The Reign of Edward III: Crown and Political Society in England, 1327-1377 (New Haven/London, 1991); Scott L. Waugh, England in the Reign of Edward III (Cambridge, 1991), in English Historical Review, 107, 384-6.

Review: Michael K. Jones and Malcolm G. Underwood, The King's Mother: Lady Margaret Beaufort, Countess of Richmond and Derby (Cambridge, 1992), Times Literary Supplement, 10 April 1992, 22.

Review: Christine Carpenter, Locality and Polity: A Study of Warwickshire Landed Society, 1401-1499 (Cambridge, 1992); Joel T. Rosenthal, Patriarchy and Families of Privilege in Fifteenth-Century England (Philadelphia, 1995), Times Literary Supplement, 31 July 1992, 22.

\section{3}

'Yorkshire justices of the peace, 1389-1413', English Historical Review, 108, 281-313.

'Home thoughts from abroad: Rome to York in 1452', Journal of Ecclesiastical History, 44, 679-88.

Review: Anthony Goodman, John of Gaunt: The Exercise of Princely Power in Fourteenth-Century England (London, 1992); C. Allmand, Henry V (London, 1992), Nottingham Medieval Studies, 27, 136-41.

Review: Michael Hicks, Richard III and his Rivals: Magnates and Their Motives in the Wars of the Roses (London, 1991), History, 78, 92-3.

Review: Michael Hicks (ed.), Profit, Piety and the Professions in Later Medieval England (Gloucester, 1990), English Historical Review, 108, 1009.

\section{4}

Ed., with Michael Jones, 'Private indentures for service in peace and war, 
1278-1476', Camden Miscellany XXXII (Camden Society 5th series, volume 3), pp. 1-190.

Review: J. S. Roskell, L. Clarke and C. Rawcliffe (eds), The history of Parliament: The House of Commons 1386-1421 (Stroud, 1993), Nottingham Medieval Studies, 38, 172-7.

Review: J. L. Catto and A. R. Evans (eds), The History of the University of Oxford, II: Late Medieval Oxford (Oxford, 1992), in Medium Ævum, 63, 170-1.

\section{5}

Ed., with Rowena E. Archer, Rulers and Ruled in Late Medieval England: Essays Presented to Gerald Harriss (London), xxvii +270 pp.

'Richard II's views on kingship', ibid., pp. 49-63.

'Political saints in later medieval England', in R. H. Britnell and A. J. Pollard (eds), The McFarlane Legacy: Studies in Late Medieval Politics and Society (Stroud), pp. 77-106.

Review: Anthony Goodman and Anthony Tuck (eds), War and Border Societies in the Middle Ages (London, 1992), in English Historical Review, 110, 987-8.

\section{6}

'Civil war and rebellion', in Christopher Given-Wilson (ed.), An Illustrated History of Late Medieval England (Manchester), pp. 229-47.

'The college and the late medieval church: the career of Richard Andrew', in J. McConica (ed.), Unarmed Soldiery: Studies in the Early History of All Souls College (Oxford: All Souls College), pp. 14-32.

Review: Andrew Ayrton, Knights and Warhorses: Military Service and the English Aristocracy Under Edward III (Woodbridge, 1994), in History, 86, 252.

Review: John Watts, Henry VI and the Politics of Kingship (Cambridge, 1996), Times Literary Supplement, 11 November 1996, 28.

Review: Michael Hicks, Bastard Feudalism (London, 1995), in Southern History, 18, 159-60.

\section{7}

Review: Nigel Saul, Richard II (New Haven/London, 1997), in London Review of Books, 4 September 1997, 16-17.

Review: S. H. Rigby, English Society in the Later Middle Ages: Class, Status and Gender (London, 1995), in English Historical Review, 112, 968-9.

Review: J. L. Kirby (ed.), The Hungerford Cartulary (Wiltshire Rec. Soc., 49, 1994), in History, 82, 307-8.

\section{8}

Review: Charles R. Young, The Making of the Neville Family in England, 11661400 (Woodbridge, 1996), in English Historical Review, 113, 702-3.

Review: Anthony Gross, The Dissolution of the Lancastrian Kingship: Sir John Fortescue and the Crisis of Monarchy in Fifteenth-Century England (Stamford, 1996), in English Historical Review, 113, 718-19. 
1999

'Janico Dartasso: chivalry, nationality and the man-at-arms', History, 84, 31-51.

'Between church and crown: master Richard Andrew, king's clerk', Speculum, 74, 956-91.

Review: Paul Strohm, England's Empty Throne: Usurpation and the Language of Legitimation, 1399-1422 (New Haven/London, 1998), in London Review of Books, 10 June 1999, 27-8.

Review: Andrew G. Watson, A Descriptive Catalogue of the Medieval Manuscripts of All Souls College, Oxford (Oxford, 1997), in English Historical Review, 114, 701-2.

Review: Richard Britnell, The Closing of the Middle Ages? England, 1471-1529 (Oxford, 1997), in English Historical Review, 114, 966-7.

2000

'Rumour, sedition and popular protest in the reign of Henry IV', Past $\mathcal{E}$ Present, 166, 31-65.

'Richard II's reputation', in Gwilym Dodd (ed.), The reign of Richard II (Stroud), pp. 119-28, 152-4.

Review: Carolyn C. Fenwick (ed.), The Poll Taxes of 1377, 1379 and 1381. Part I: Bedfordshire-Leicestershire (Oxford, 1998), in English Historical Review, 115, 701-2.

Review: Michael Hicks, Richard III (Stroud, 2000), Times Literary Supplement, 20 October 2000, 30.

\section{1}

Review: Helen Castor, The King, the Crown, and the Duchy of Lancaster: Public Authority and Private Power (Oxford, 2000), Times Literary Supplement, 26 January 2001, 32.

Review: Colin Richmond, The Paston Family in the Fifteenth Century: Endings (Manchester, 2000), Times Literary Supplement, 3 August 2001, 25.

\section{3}

'The Yorkshire risings of 1405: texts and contexts', in Gwilym Dodd and Douglass Briggs (eds), Henry IV: The Establishment of the Regime (York), pp. 161-84.

'Remembering Richard: history and memory in Lancastrian England', in Christine Carpenter and Linda Clark (eds), Political Culture in Late Medieval England (The Fifteenth Century, IV, Woodbridge), 21-31.

Review: Jonathan Hughes, Arthurian Myths and Alchemy: The Kingship of Edward IV (Stroud, 2002), in London Review of Books, 10 July 2003, 25-7.

Review: Ann Wroe, Perkin: A Story of Deception (London, 2003), Times Literary Supplement, 11 April 2003, 28. 


\section{4}

14 articles in Oxford Dictionary of National Biography:

Abberbury family (per. c. 1270-c. 1475), 1:6-7

Dartasso, Janico (d. 1426), 15:171-2

Erpingham, Sir Thomas (c. 1355-1428), 18:512-14

Farrington, Sir William (c. 1348-1416/17), 19:130-1

Grey, John, third Baron Grey of Codnor (1305'x11?-1392), 23:861-2

Hastings family (per. c. 1300-c. 1450), 25:730-1

Ive, William (d. 1486), 29:445-6

John, duke of Aquitaine and duke of Lancaster, styled king of Castile and León (1340-1399), 30:174-83

Katherine, duchess of Lancaster (1350?-1403), 30:888-90

Lovell, John, fifth Baron Lovell (c. 1342-1408), 34:524-5

Maidstone, Clement (c. 1389-1456), 36:163

Percy, Sir Henry (1364-1403), 43:702-4

Pole, Michael de la, second earl of Suffolk (1367/7-1415), 44:713-14

Sudbury, Simon (c. 1316-1381), 53:271-4

2006

'Order and law', in Rosemary Horrox and Mark Ormrod (eds), A Social History of England, 1200-1500 (Cambridge, 2006), pp. 91-112.

\section{Forthcoming}

Ed., The Building Accounts of All Souls College, 1438-1443 (Oxford Historical Society, n.s. 31).

'Les deux procès de Richard Scrope, archevêque de York, 1405-1406', in Brigitte Marin (ed.), Les procès politiques (XIVe-XVIIe siècles) (Collection de l'École Française de Rome). 
Simon Walker - 9781526148223

Downloaded from manchesterhive.com at 04/26/2023 02:51: ๑2PM 